Proceedings

\title{
Analyzing and mapping heatwave vulnerability and urban sus- tainability - the case of largest Hungarian cities
}

\author{
Attila Buzási ${ }^{1, *}$, Bettina Szimonetta Jäger ${ }^{1}$ and Olivér Hortay ${ }^{2}$
}

1 Budapest University of Technology and Economics, Department of Environmental Economics and Sustainability; buzasi.attila@gtk.bme.hu; jager.szimonetta@gtk.bme.hu

2 Budapest University of Technology and Economics, Department of Finance; hortay.oliverl@gtk.bme.hu

* Correspondence: buzasi.attila@gtk.bme.hu

Citation: Buzási , A., Jäger , B.S., Hortay , O. Analyzing and mapping heatwave vulnerability and urban sustainability - the case of largest Hungarian cities. SUPTM 2022 conference proceedings sciforum- 050260 . https://doi.org/ 10.31428/10317/10480

Publisher's Note: UPCT and Sciforum stays neutral with regard to jurisdictional claims in published maps and institutional affiliations.

Copyright: (c) 2022 by the authors. Submitted for possible open access publication under the terms and conditions of the Creative Commons Attribution (CC BY) license (https://creativecommons.org/license s/by/4.0/).

\begin{abstract}
Urban sustainability and climate adaptation are major challenges in current urban areas; therefore, they can be seen as relevant issues in Hungary. This study aims to comparatively analyze the overall sustainability and heatwave-related vulnerability of the largest Hungarian cities. The applied methodology is based on different data types; however, the indicator method is in its focus: firstly, socio-economic statistical data are collected from the Hungarian Central Statistical Office; secondly, remote sensing data is retrieved from the USGS database. The mixed methodology can provide the opportunity to reveal complex issues regarding urban sustainability and heatwave vulnerability as the main challenges of the Hungarian cities nowadays.
\end{abstract}

Keywords: urban sustainability; heatwave; comparative analysis; mixed methodology

\section{Introduction}

Urban areas have gained significant attention from the international scientific community in terms of sustainability [1-4] - and more recently - and climate-related issues in the previous decades [5,6]. The growing literature indicates the unquestionable importance of cities facing various climatic and sustainability challenges that pose decisionand strategy-makers to reveal hidden relationships behind the complex and dynamic urban processes [7-9]. Cities are highly concentrated areas regarding their specific social, economic and environmental features through the constantly increasing global urban population, their immense economic power, and the different emissions related to various environmental challenges and even climate change $[10,11]$. Consequently, there is an unquestionable need for detailed analyses regarding cities' sustainability and climate-related performance [12,13]. The Hungarian cities face almost the same challenges as the other European urban areas; however, they are rarely studied regarding their complex sustainability or climate adaptation performance $[14,15]$. According to previous studies, regional climate models projected intensive heatwave events in the Carpathian basin $[16,17]$; thus, Hungarian cities must be prepared and adapted to those extreme climatic features.

This study aims to comparatively analyze the overall sustainability and heatwaverelated vulnerability of the largest Hungarian cities (with a population over or just around $100.000 \mathrm{ppl}$ ). The applied methodology is based on different types of data: open-access socio-economic statistical data are collected from the Hungarian Central Statistical Office; land-use and land-cover information are retrieved from the Urban Atlas database; finally, remote sensing data were retrieved from the NASA Landsat- 8 database. The following sections briefly summarize the applied methodology by introducing the selected indicators, followed by the main results regarding the performance-based comparison of the selected cities, and concluding statements at the end of the paper. 


\section{Methodology}

This study aims to describe the overall sustainability and heatwave-related vulnerability of the largest Hungarian cities with a population of over 100.000; therefore, the following cities were involved in the analysis: Győr, Székesfehérvár, Pécs, Kecskemét, Szeged, Nyíregyháza, Debrecen, and Miskolc. Moreover, since Budapest, the capital of Hungary, has around 1.7 million, the 23 districts have also been involved; however, most of them do not reach the $100.000 \mathrm{ppl}$ threshold, their specific legal status, economic power, and importance make them relevant studied units.

The selected indicators represent the most relevant categories regarding urban sustainability and heatwave vulnerability, such as economic, social, and environmental sustainability aspects; moreover, sensitivity and adaptive capacity variables (see Table 1). Each category includes four indicators in order to represent the same variety of different sustainability and vulnerability issues. Economic sustainability variables focus on the economic viability of the selected cities; social indicators show the stability and long-term sustainability of the given cities' societies, while environmental indicators cover green areas, resource consumption, and transport-oriented aspects. Heatwave vulnerability was described by involving eight variables from population density, aging index, the ratio of most vulnerable social groups, and the ratio of people with cardiovascular diseases as sensitivity indicators focusing on the intrinsic factor of vulnerability to adaptive capacity variables which cover the ability of given societies to cope with the adverse effects of climate change. Two indicators, namely the green areas per capita and NDVI (Normalized Difference Vegetation Index), were calculated by collecting remote sensing data from Landsat-8 imageries $^{1}$ and Urban Atlas database ${ }^{2}$ and transforming them with QGIS software. All of the collected information is related to the years 2014 and 2019 to reveal the temporal change of overall sustainability and heatwave vulnerability of the selected Hungarian cities.

Since the raw data were in totally different units, a linear transformation has been made to define the normalized values of each indicator. In the case of sustainability analysis, 0 values represent the worst performance, and 1 shows the best values. In contrast, in the case of vulnerability, the opposite approach was followed to illustrate the relative and consequently comparable performance of the selected units. The overall sustainability and vulnerability values were calculated by using the unweighted averages of each indicator.

Table 1. Selected indicators.

\begin{tabular}{c|c|c|c|c}
\hline \multicolumn{2}{|c|}{ Sustainability } & \multicolumn{2}{c}{ Heatwave vulnerability } \\
\hline $\begin{array}{c}\text { Economic } \\
\text { Sof taxpayers per } \\
1000 \mathrm{ppl}\end{array}$ & Aging index & Green areas per capita & Population density & No. of GPs per 1000 ppl \\
\hline $\begin{array}{c}\text { Early career unemploy- } \\
\text { ment rate }\end{array}$ & Migration rate & $\begin{array}{c}\text { Energy consumption } \\
\text { per capita }\end{array}$ & Aging index & NDVI \\
\hline $\begin{array}{c}\text { No. of enterprises - RDI } \\
\text { sector }\end{array}$ & $\begin{array}{c}\text { No. of divorces per 1000 } \\
\text { ppl }\end{array}$ & $\begin{array}{c}\text { Length of bicycle lanes } \\
\text { and sidewalks per cap- } \\
\text { ita }\end{array}$ & $\begin{array}{c}\text { Ratio of ppl with age } \\
65+\text { and 0-2 }\end{array}$ & $\begin{array}{c}\text { Yearly income per cap- } \\
\text { ita }\end{array}$ \\
\hline $\begin{array}{c}\text { Ration of newly built } \\
\text { dwellings }\end{array}$ & $\begin{array}{c}\text { No. of crimes per } 1000 \\
\text { ppl }\end{array}$ & Vehicular load & Cardiovascular diseases & Unemployment rate \\
\hline
\end{tabular}

\section{Results}

Due to the length constraints of this paper, only overview results from the year 2019 can be seen in Figure 1. Five outliers were distinguished with green and red colors: three

${ }^{1}$ https://earthexplorer.usgs.gov

2 https://land.copernicus.eu/local/urban-atlas 
districts $\left(5^{\text {th }}, 6^{\text {th }}\right.$, and $\left.7^{\text {th }}\right)$ of Budapest can be described with above-average heatwave vul- 1 nerability and below-average sustainability scores, which pose them in the danger zone. Since the mentioned districts are in the warmest downtown area in Budapest, it is unquestionably crucial to reduce their vulnerability since their relatively low sustainability performance makes them extremely sensitive and, consequently, vulnerable to future changes. On the opposite side, Györ and Kecskemét can be found with high sustainability and low vulnerability scores. These two cities are not surprisingly lie in this section: they are one of the most prosperous cities in Hungary with a high proportion of automotive industry in their economic structure, well-managed universities, and attracting urban fabric. The rest of the cities' position needs further detailed analyses to reveal relevant spatiotemporal patterns and define the most rapidly changing urban areas of the largest Hungarian towns.

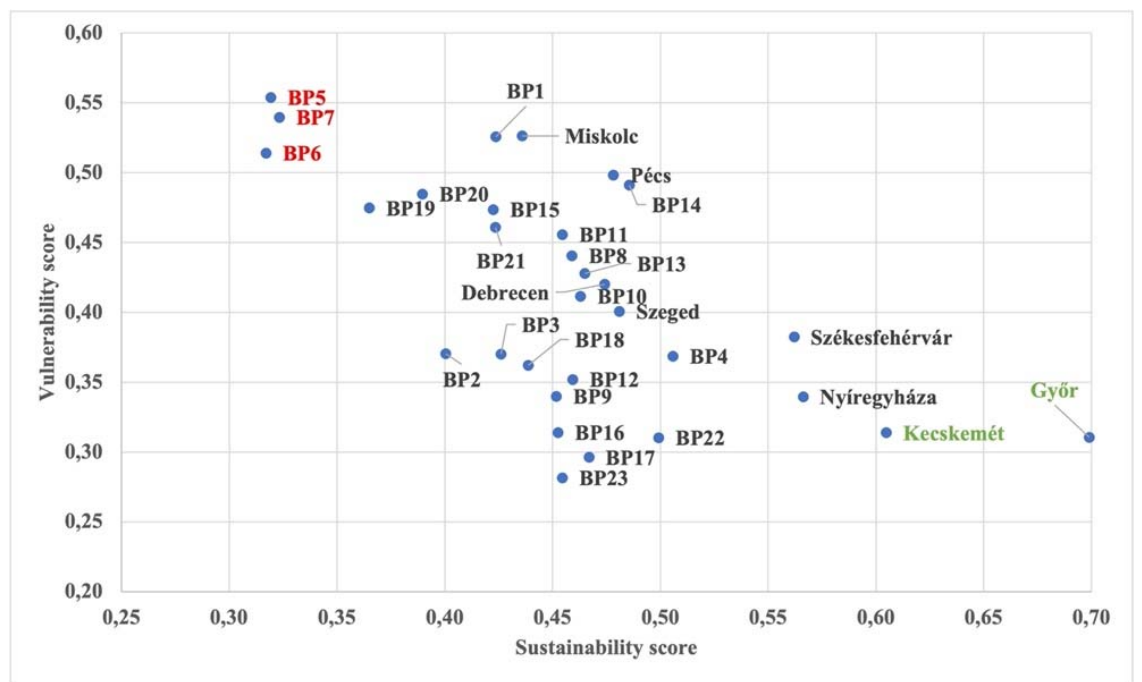

Figure 1. Average sustainability and vulnerability scores

\section{Conclusion}

Revealing and analyzing the relative sustainability and heatwave-related vulnerability performances were at the center of the present study. For this reason, socio-economic indicators and remote sensing data were retrieved and normalized. Finally, the unweighted averages represented the overall values. Since the Hungarian cities are rarely studied in terms of sustainability or climate adaptation issues, this paper seems to be an initial result of further detailed analyses of spatial and temporal assessments. The results shed light on the existing east-west axis of Hungary. Generally, Western-Hungarian cities performed much better based on the selected indicators. Moreover, Budapest's downtown districts are at the bottom of the ranking, making the above-average vulnerable to present and future changes. Further analyses shall focus on more cities by involving other county seats in order to strengthen the statistical analyzability of data.

Funding: Project no. 137595 has been implemented with the support provided by the Ministry of Innovation and Technology of Hungary from the National Research, Development and Innovation Fund, financed under the FK_21 funding scheme.

Conflicts of Interest: The authors declare no conflict of interest. 


\section{References}

\section{1}

1. Feleki, E.; Vlachokostas, C.; Moussiopoulos, N. Characterisation of sustainability in urban areas: An analysis of assessment tools with emphasis on European cities. Sustain. Cities Soc. 2018, 43, 563-577, doi:10.1016/j.scs.2018.08.025.

2. Zinatizadeh, S.; Monavari, S.M.; Azmi, A.; Sobhanardakani, S. Evaluation and prediction of sustainability of urban areas: A case study for Kermanshah city, Iran. Cities 2017, 66, 1-9, doi:10.1016/j.cities.2017.03.002.

3. Way, H. Beyond the Big City: The Question of Size in Planning for Urban Sustainability. Procedia Environ. Sci. 2016, 36, 138145, doi:10.1016/j.proenv.2016.09.024.

4. Marvuglia, A.; Havinga, L.; Heidrich, O.; Fonseca, J.; Gaitani, N.; Reckien, D. Advances and challenges in assessing urban sustainability: an advanced bibliometric review. Renew. Sustain. Energy Rev. 2020, 124, 109788, doi:10.1016/j.rser.2020.109788.

5. Tozer, L. Urban climate change and sustainability planning: an analysis of sustainability and climate change discourses in local government plans in Canada. J. Environ. Plan. Manag. 2018, 61, 176-194, doi:10.1080/09640568.2017.1297699.

6. Elmqvist, T.; Andersson, E.; Frantzeskaki, N.; McPhearson, T.; Olsson, P.; Gaffney, O.; Takeuchi, K.; Folke, C. Sustainability and resilience for transformation in the urban century. Nat. Sustain. 2019, 2, 267-273, doi:10.1038/s41893-019-0250-1.

7. Hölscher, K.; Frantzeskaki, N.; McPhearson, T.; Loorbach, D. Tales of transforming cities: Transformative climate governance capacities in New York City, U.S. and Rotterdam, Netherlands. J. Environ. Manage. 2019, 231, 843-857, doi:10.1016/j.jenvman.2018.10.043.

8. Hodson, M.; Geels, F.W.; McMeekin, A. Reconfiguring urban sustainability transitions, analysing multiplicity. Sustain. 2017, 9, doi:10.3390/su9020299.

9. Romero-Lankao, P.; Bulkeley, H.; Pelling, M.; Burch, S.; Gordon, D.J.; Gupta, J.; Johnson, C.; Kurian, P.; Lecavalier, E.; Simon, D.; et al. Urban transformative potential in a changing climate. Nat. Clim. Chang. 2018, 8, 754-756, doi:10.1038/s41558-0180264-0.

10. Cohen, M. A systematic review of urban sustainability assessment literature. Sustain. 2017, 9, 1-16, doi:10.3390/su9112048.

11. Bai, X.; Dawson, R.J.; Ürge-Vorsatz, D.; Delgado, G.C.; Salisu Barau, A.; Dhakal, S.; Dodman, D.; Leonardsen, L.; MassonDelmotte, V.; Roberts, D.C.; et al. Six research priorities for cities and climate change. Nature 2018, 555, 23-25, doi:10.1038/d41586-018-02409-z.

12. Corredor-Ochoa, Á.; Antuña-Rozado, C.; Fariña-Tojo, J.; Rajaniemi, J. Challenges in assessing urban sustainability. Urban Ecol. 2020, 355-374, doi:10.1016/b978-0-12-820730-7.00019-7.

13. Zhang, X.; Li, H. Urban resilience and urban sustainability: What we know and what do not know? Cities 2018, 72, 141-148, doi:10.1016/j.cities.2017.08.009.

14. Szalmáné Csete, M.; Buzási, A. Hungarian regions and cities towards an adaptive future - analysis of climate change strategies on different spatial levels. Időjárás 2020, 124, 253-276, doi:10.28974/idojaras.2020.2.6.

15. Buzási, A.; Jäger, B.S. Exploratory analysis of urban sustainability by applying a strategy-based tailor-made weighting method. Sustain. 2021, 13, doi:10.3390/su13126556.

16. Pongrácz, R.; Bartholy, J.; Bartha, E.B. Analysis of projected changes in the occurrence of heat waves in Hungary. Adv. Geosci. 2013, 35, 115-122, doi:10.5194/adgeo-35-115-2013.

17. Göndöcs, J.; Hajnalka, B.; Pongrácz, R.; Bartholy, J. Projected changes in heat wave characteristics in the Carpathian Basin comparing different definitions. Int. J. Glob. Warm. 2018, 16, 119-135, doi:10.1504/IJGW.2018.094552.
3 